\title{
The Key-role of Eladio Dieste, Spain and the Americas in the Evolution from Brickwork to Architectural Form
}

\author{
Jose Maria Cabeza Lainez*¹, Juan Ramon Jimenez Verdejo ${ }^{2}$, Benito Sanchez-Montanes Macias ${ }^{3}$ and \\ Jose Ignacio Perez Calero
}

\author{
${ }^{1}$ Professor, School of Architecture, University of Seville, Spain \\ ${ }^{2}$ Lecturer, School of Architecture, University of Shiga Prefecture, Japan \\ ${ }^{3}$ Associate Professor, School of Architecture, University of Seville, Spain
}

\begin{abstract}
In this paper the authors intend to outline the genius of Eladio Dieste, a Uruguayan creator whose architectural expression could be defined as truly modern for America and the world. His leitmotiv was the use of science and technology to solve not only formal but also social problems. Dieste excelled in the search for economic techniques adequate for enhancing creativity and human dignity. His avant-garde solutions are rooted in tradition and thus reflect the true character and untamed force of the Americas. He offered a new basis on which to cement a sustainable architecture of unquestioned prevalence in this nature-blessed continent.

The authors are dealing here with something rather unusual in the field of building construction: an almost isolated author capable of introducing technical innovations, which can be both poetical and environmentally friendly. A builder who, confronted with the vast expansions of his native plains, invents a new tradition to put science at the service of people and architecture. The voice of underdeveloped countries is distinctly heard in the soft tones of Eladio Dieste's architectural works. As his legacy has been somehow neglected, it is our hope with the present discussion on some of Dieste's design insights to revive his methods and make architects more aware of the real significance of his compassionate and yet unequalled mastery.
\end{abstract}

Keywords: modern architecture; roussillon vaults; brick shell construction; laminar construction

\section{Introduction}

Educated as an engineer, Eladio Dieste (1917-2000), produced between 1945 and 1975 a whole set of outstanding architectural works that enhanced a simple traditional material like brick or masonry conferring upon it both the ductility and mechanical capacity of reinforced concrete at the same time by virtue of a hybrid technique that will be called for now "reinforced ceramic construction". ${ }^{1)}$

The idea of compensating for the lack of tensile strength of stone materials and especially masonry has been recurrent throughout history. Nonetheless, this practice became increasingly popular when metallic materials experienced an unprecedented evolution, which culminated with the mass production of iron and especially of steel. Previously the role of metals, although abundant in weapons and warfare, had been very limited in building construction. ${ }^{2)}$

*Contact Author: Jose Maria Cabeza Lainez, Professor of the School of Architecture at the University of Seville, 6-4-33, Fukui, Nishi-ku, Sapporo, 063-0012 Japan

Tel: +81-11-663-4943 Fax: +81-11-663-4943

E-mail:wrzescz@gmail.com

(Received April 7, 2009 ; accepted July 26, 2009)
Such industrial uses of steel introduced a set of architectural procedures that in the long run made the work of Eladio Dieste possible. In a short historical recollection, the authors have found that those types of architecture are by all means connected to a certain constructive tradition stemming from the $20^{\text {th }}$ century and even before. They believe that this tradition has much to do with the remembrance of the

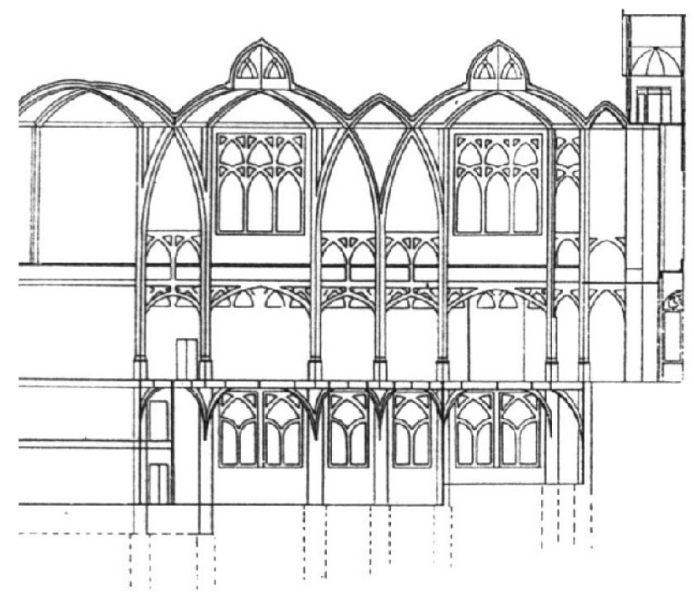

Fig.1. Section Through the Nave of the Church of Saint Jean de Montmartre 
Mediterranean $^{3)}$ and the use of discrete and humble materials, in many cases hand-produced.

\section{Evolution of the System}

While the vicissitude of reinforced concrete with the achievements of Hennebique and others is well known, this was not the case regarding the French Engineer Paul Cottancin's patenting of the system of ciment armé, in 1890, which mainly consisted of brick elements interspersed with wires and cement layers.

Such a discovery immediately interested architects like Anatole De Baudot who employed it successfully in his church of Saint Jean de Montmartre. The intricate vaults of Saint Jean are related to a series of grande salle projects completed by Baudot like the proposal for the Paris Exposition of 1900. In these projects the advantages and inconveniences of adopting the novel brick technique can be clearly understood. As expected, the complexity of the system soon rendered it out of date.

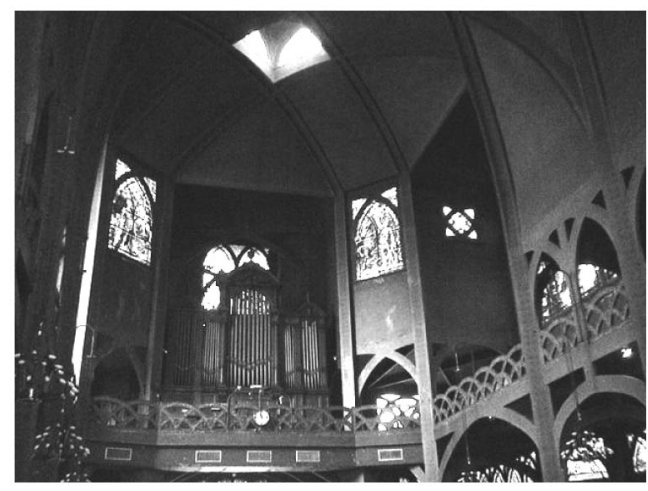

Fig.2. Interior of the Church of Saint Jean de Montmartre. Paris.

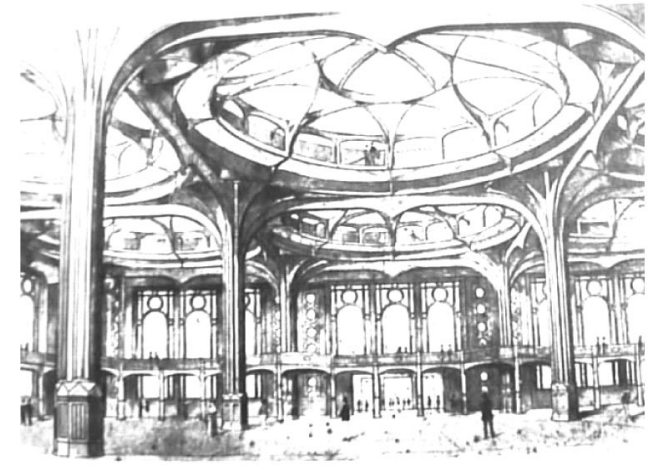

Fig.3. A Famous Grande Salle Project by De Baudot

At about the same time and on the other side of the Atlantic, the architect Rafael Guastavino, born in Valencia, had shown, especially in the East Coast area of Spain, the many possibilities of what he called cohesive construction. ${ }^{4}$

That term roughly equated to a roofing technique based on a unique type of masonry known as Roussillon or Catalan vaults. In summary, they are curved roofs composed of one or several layers of thin hollow brick (rasilla), in which the lower of them

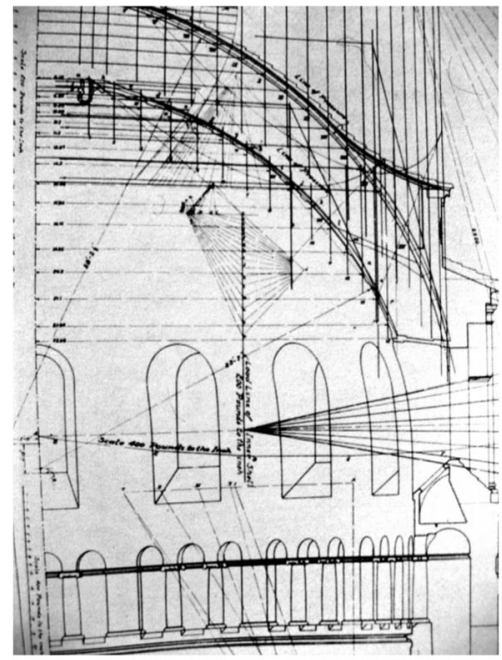

Fig.4. Construction Drawing of Guastavino and Co. for the Saint Paul Chapel at the University of Columbia (1905-1906)

is inlaid with gypsum mortar, thus achieving almost immediate stiffness and allowing the use of permanent scaffolding to be almost avoided.

However, there is every reason to believe that the vaults came previously to Latin America with the Spaniards. McAndrew reports them in the Capilla Real of Cholula in the mid-sixteenth century, assuming them to be of local invention. ${ }^{5}$

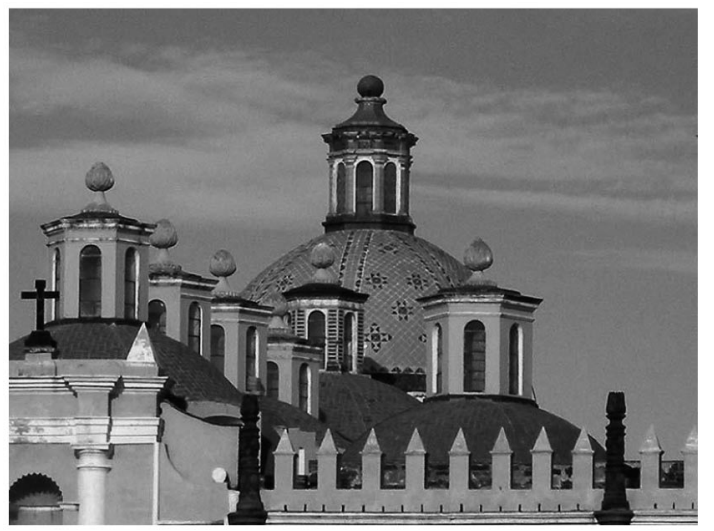

Fig.5. The Capilla Real of Cholula Near Puebla (Mexico) with 49 Domes, 23 of which were Opened for Lighting and Ventilating Purposes ${ }^{6}$

They very likely came from Spain but not, as he notes, from any of the Spanish Muslim structures which the chapel otherwise resembles. The only earlier North American examples were Robert Mill's ingenious cohesive vaults in Washington, D. C., which seem to have had no imitations. They may have sprung from the French tradition, as is suggested by Bannister. ${ }^{7)}$

It remains unclear if Guastavino and Co. included any type of steel reinforcement inside these constructions. Be this as it may, such works proved economical and not exempt of dignity and the Company attained nation-wide recognition. ${ }^{8)}$

The Guastavinos, father and son, developed in the 


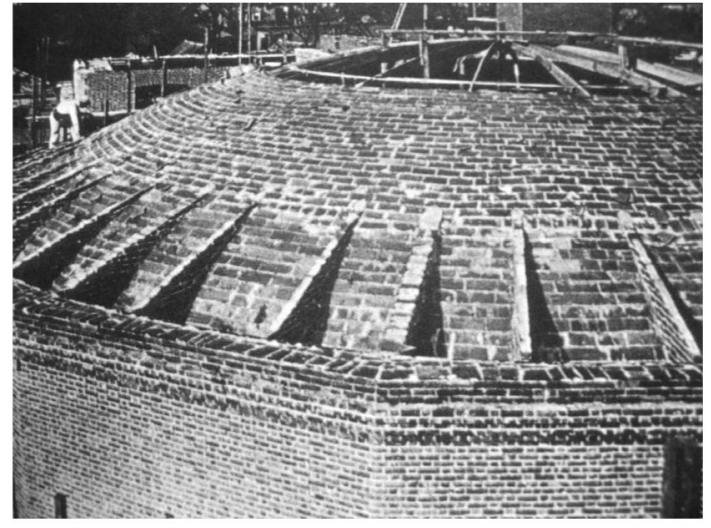

Fig.6. R. Guastavino. East Boston High School. 1899

USA and to a wider scale, construction techniques which had thrived in the Mediterranean for many years and, at the beginning of the twentieth century, were still alive within local guilds of masons. Guastavino is buried in Asheville (NC) and a distinguished admirer, the structural engineer and architect Felix Candela, even chose the same cemetery for his interment as posthumous homage ${ }^{9)}$.

The said Mediterranean connection is evident when we analyze for example the first cable-buttressed vaults of the Garraf Houses (Costa Brava) of 1935 by Torres Clave and Josep Lluis Sert ${ }^{10)}$.

Sert resorted to this construction type from Massachusetts, where he was dean of the Faculty of Architecture, when in 1954 he projected and built the atelier for the painter Joan Miro in Palma de Majorca. ${ }^{11)}$

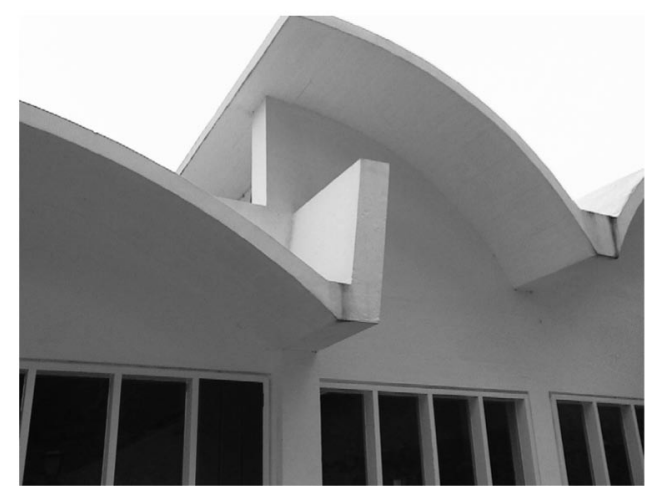

Fig.7. The Atelier for the Painter Joan Miro in Palma de Majorca Designed by Josep Lluis Sert (1954)

Around this time and probably to the approval of Sert, a great many substantive facts had taken place for our story. One of these facts reveals itself in the project of the Maisons Jaoul by Le Corbusier which, although initiated in the 1930 s was not actually built until 1952. This project much alarmed the late architect Sir James Stirling for its want of any type of industrialised material as it was composed chiefly of stone walls and brick vaults. One of the main contributors to the building was the young architect Antoni Bonet. ${ }^{12)}$

Bonet, who was not eager to return to post-war Spain, established a practice in Buenos Aires in
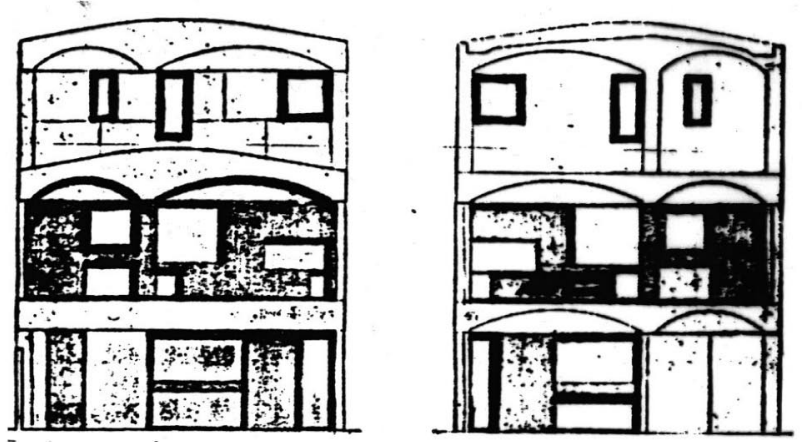

Fig.8. The Maisons Jaoul by Le Corbusier

association with the Argentinean architects Ferrari and Kurchan. In one of their first projects for the capital of the Plata River, the atelier at the crossroad of Suipacha and Paraguay, he commissioned Eladio Dieste with the construction of the Catalan vaults. The Uruguayan decided on the provision of a steel reinforcement for the structure since the vaults suggested by Bonet were excessively steep.

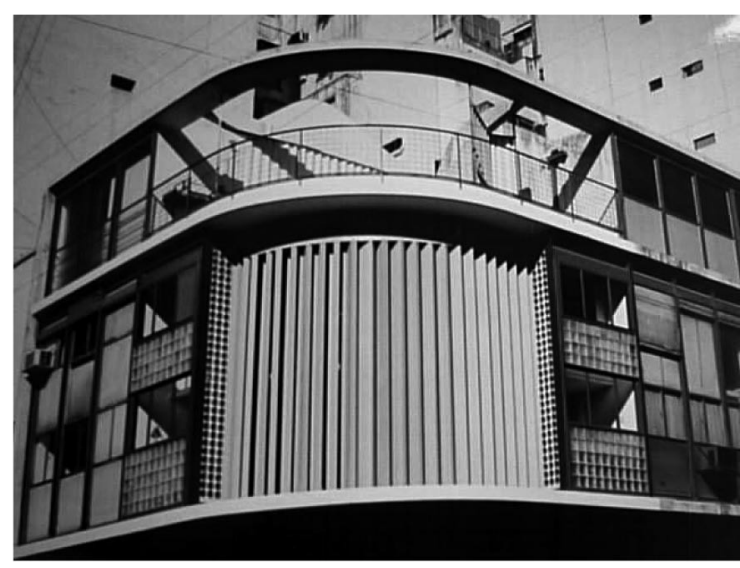

Fig.9. Ateliers at the Crossing of Suipacha and Paraguay Streets with Vaulted Penthouses (Buenos Aires).

Bonet, Ferrari and Kurchan

\section{Techniques of Analysis}

The procedures for structural analysis devised by Dieste in order to realize his "ceramic shells" are not very different from those simplified methods usually employed, under the general denomination of the Lundgren method, for the calculation of cylindrical concrete shells. ${ }^{13)}$

Curious variations appear though as functions of material and curvature of the shells. A superb example of this appeared in 1936 in the port of Wakkanai, Hokkaido (Japan). It is a breakwater dome 424 metres long and 13.8 metres high designed by Tsuchiya Minoru. ${ }^{14)}$

The Lundgren method is usually referred to as the "beam theory" since its main principle is to assume that the whole shell performs as a great beam whose cross section is the arch defined by the laminar profile selected. 


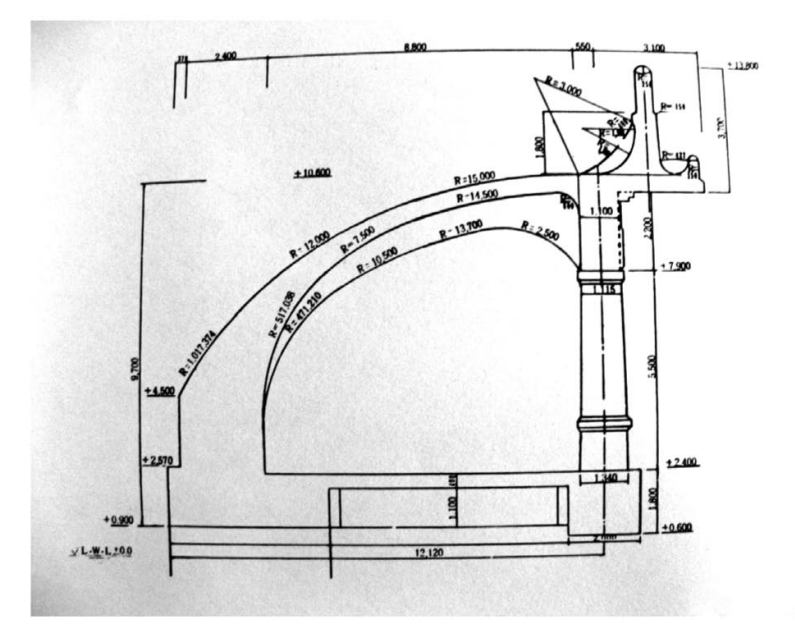

Fig.10. Section of Wakkanai Breakwater Dome by Tsuchiya Minoru

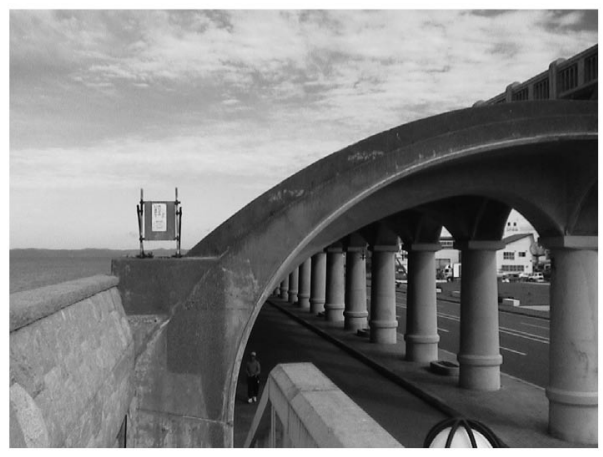

Fig.11. Recent View of Wakkanai Breakwater dome (Hokkaido). Photograph: Jose Maria Cabeza Lainez

In such conditions the well-known formulas in Resistance of Materials, which introduce the bending moment divided by the moment of resistance of the cross section may be employed. By virtue of these we could obtain the stresses along the generatrices of the shell as:

$$
N_{x}=\frac{M_{y y}}{I_{y y}} * z * d
$$

where $I_{v y}$, is the moment of inertia at the y axis (vertical in a symmetrical membrane). ${ }^{15)}$

It is also possible to find the shear stresses by means of the second law in materials science namely:

$$
N_{x \phi}=\frac{V^{*} Q}{2 * I_{y y}}
$$

Above, $\mathrm{V}$ represents the stresses and Q is the static moment of the section.

Once this stress distribution has been found, the analysis is completed considering the shell as a continuous arch and applying any system of calculation of hyperstatic arches, such as the Column Analogy presented by Hardy Cross, around $1930^{16)}$. Thus, we will eventually obtain other relevant stresses as for instance $\mathrm{N}_{\varphi}, \mathrm{M}_{\varphi}$ or $\mathrm{M}_{\mathrm{x}}$.

Provided that the stresses are given by this or other

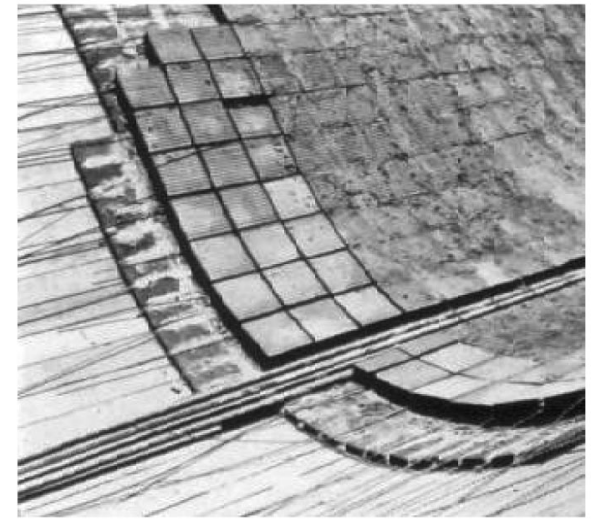

Fig.12. Reinforcement Bars between Blocks used by Dieste in the Atlantida Church

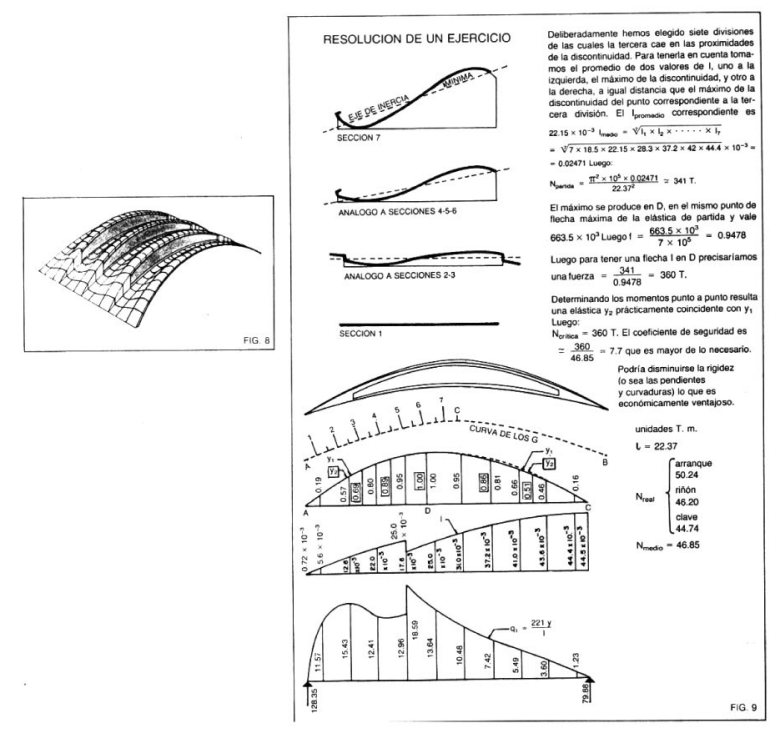

Fig.13. Examples of Calculations of gausas Vaults or Ruled Surface Vaults (from French: gauches). Eladio Dieste

supplementary systems it is remarkable that Dieste had to resort to traditional methods of materials science to determine the reinforcement bars needed for his shells ${ }^{17}$. In other words, the methods used for reinforced concrete such as the parabola-rectangle principle or the maximum moment law are not suitable here because the strains differ considerably from the ones usual found in concrete shells.

Obviously the conglomerate of brick, cement and steel is more heterogeneous than ferro-concrete and in this case it seems feasible to assume that the tensile stresses will be absorbed in their entirety by the available steel while the compression stress is transferred to the brick or rather the compound of brick and mortar. It is also noticeable that similar approaches are given when we apply the finite element method.

Dieste hardly ever included coefficients of load increase in his calculations and that contributed to a great extent to the slenderness of his design solutions at the cost of exponentially complicated calculations to cope with unpredictable effects. His fundamental reference in this respect was the book by the Hungarian 
engineer Hetényi, a follower of Timoshenko, which he used to complete the calculations of strains and ratio of bending moments for a series of arched frames.

Dieste usually tried to reinforce his structures by following the isostatic lines but today it is generally admitted that to dispose steel bars following diagonal lines in the plan of the proposed shell is more costeffective.
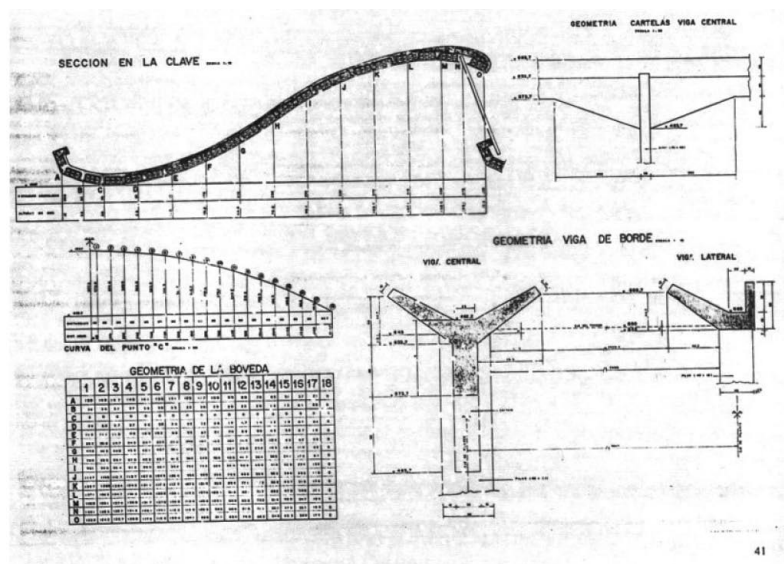

Fig.14. Section of the gausas Vaults, Beams and Calculation Tables by Dieste

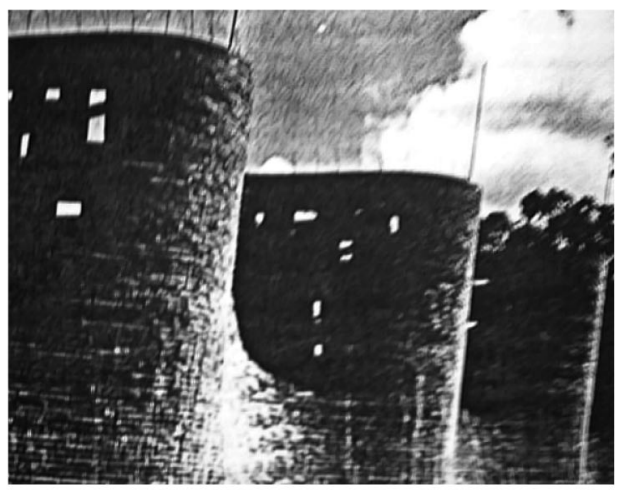

Fig.15. The Works of the Wall of Atlantida Church in Canelones (Uruguay). 1958.

Probably Dieste's Most Important Architectural Work

\section{Parallels in America and Spain}

Apart from his own company, Eladio Dieste found no other architects working in his wake. Despite this fact, some interesting experiences with ceramic shells took place in America and Spain. The authors will discuss them briefly.

1. Eduardo Torroja and the Pont de Suert Church

The authors would first cite the example of the Spanish Engineer Eduardo Torroja who, in a church at Pont de Suert in Lerida, Spain (1954), designed curved walls and vaults made of a thin terracotta tile called rasilla. Torroja arranged the tiles in three layers, the interior one lined with tenacious gypsum mortar and the exterior reinforced with smooth steel bars which could be added in other parts of the structure if need be. For reasons unknown to us, the system was never to be employed again. Some believe that the progressive

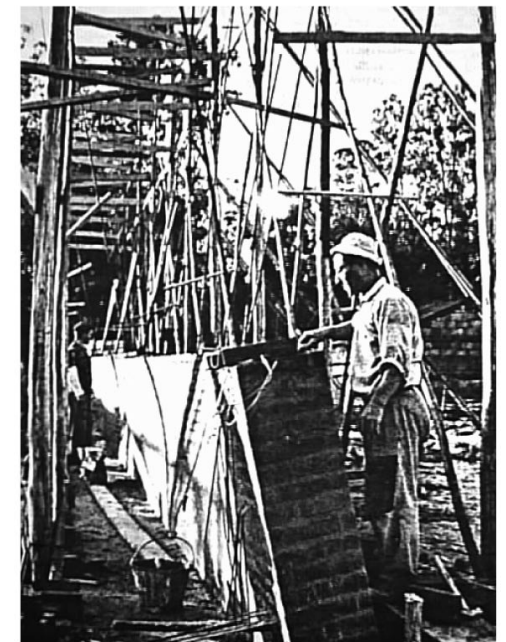

Fig.16. The Initial Stage of the Construction of the Conoidal Walls of Atlantida Church

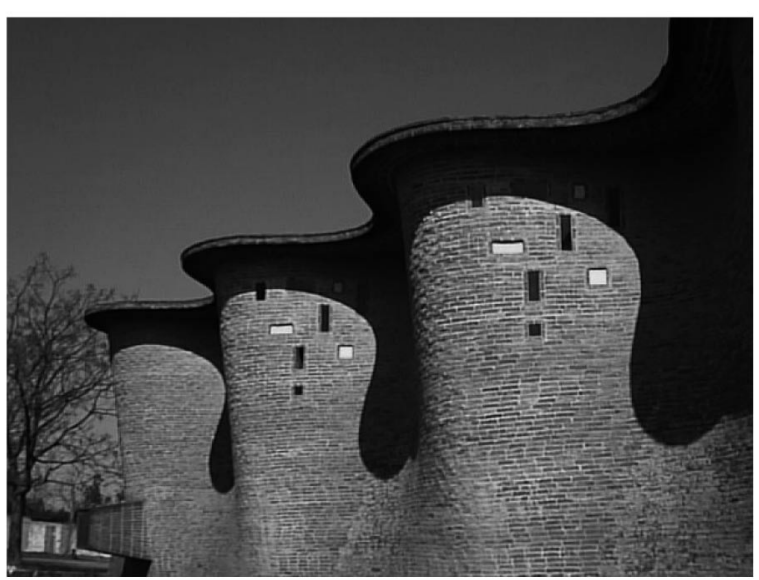

Fig.17. Recent View of the Atlantida Church. Photograph: Jose Maria Cabeza Lainez

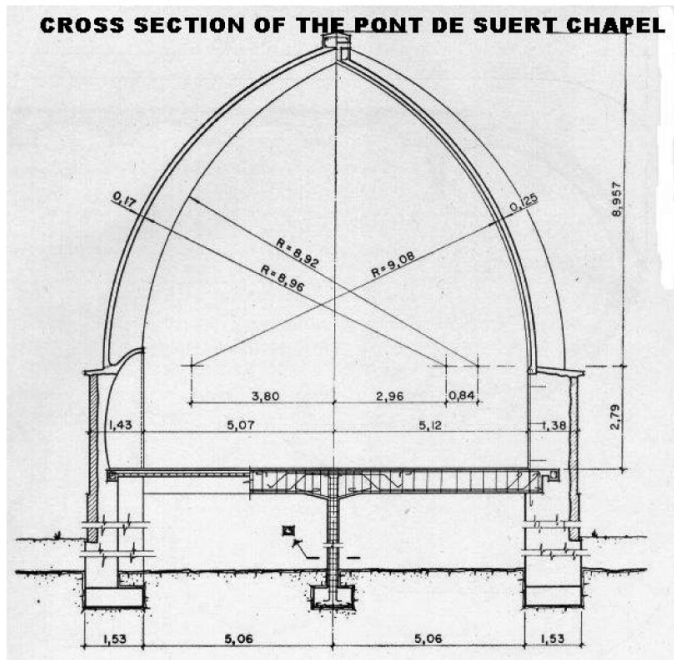

Fig.18. Sectional Drawing of the Church at Pont de Suert Showing the Curved Nave

diminution of workers familiar with this technique dissuaded him from further usage of his adroit ceramic structure. $^{18)}$ 


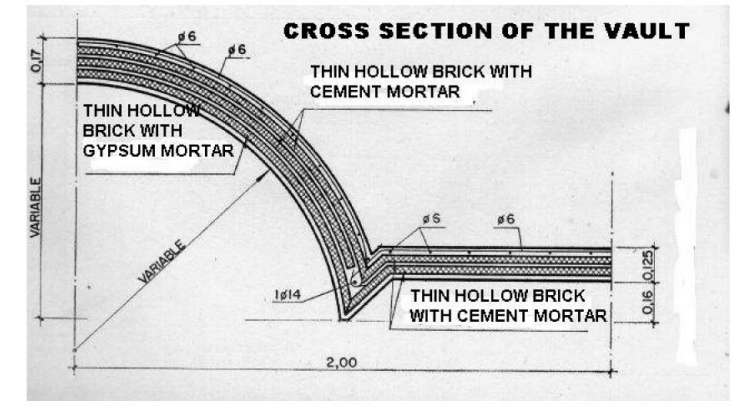

Fig.19. Detail of One of the Chapels of the Pont de Suert Church, Composed of Brick Masonry and Reinforcement Bars

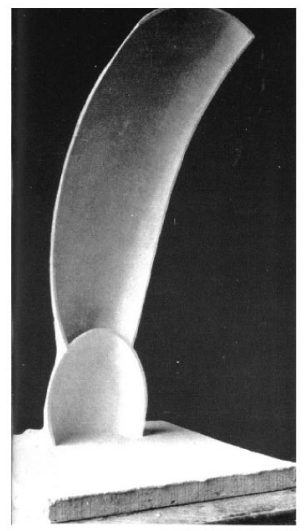

Fig.20. Scale Model of One of the Chapels

\section{Cuba's unfinished Art Schools}

In 1959 Fidel Castro and Che Guevara decided to build a group of new art schools at the site of a once prestigious golf club. Castro himself commissioned the construction to the young architect Ricardo Porro. Porro, who had studied in Havana and Paris, was reportedly an admirer of the last expressive works of Le Corbusier. Together with two Italian friends, Vittorio Garatti and Roberto Gottardi, he started with the design in 1961, only a few days after the Bay of Pigs incident.

Porro assumed the leading role in the project for the school of modern dance and plastic arts; Roberto Gottardi designed the school of dramatic arts and Vittorio Garatti the school of music and ballet.

Under Castro's approval, Porro chose the Catalan vaults as the main structural system. Its budget was reasonable and allowed for unusual expression that could serve as a symbol for the young Cuban revolution. All buildings explored the potential of the material, producing arrays of domes and sequences of barrel vaults. The way in which those buildings dealt with the urban and spatial problems while answering to the surrounding landscape makes this complex one of the most important architectural creations since the beginning of the 1960s. ${ }^{19)}$

However, the accomplishment of such projects relied mainly on a humble mason whose father had worked for Gaudi in Barcelona. The real scale models constructed by him helped to overcome the

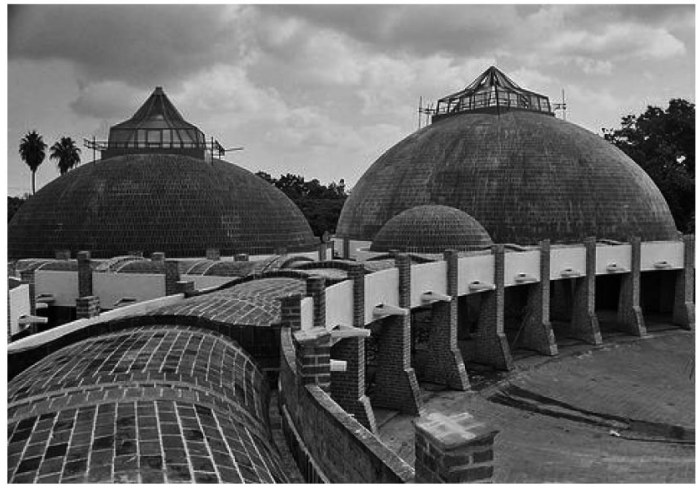

Fig.21. Ricardo Porro, School of Plastic Arts (Cuba)

understandable scepticism of the authorities. Initially, the construction works on the schools progressed at a fast pace. Later on, due to the difficult political situation and the missile crisis of 1962, the construction was almost abandoned and eventually the schools were officially inaugurated before actually finishing them. A simultaneous increase of pressure from the USSR entailed more emphasis on prefabrication and forced a return to rationalistic principles. In 1968 the Catalan vaults were criticized for being individualistic, monumental and authoritarian, instead of scientific, flexible and efficient. ${ }^{20)}$

\section{Recent Developments}

In a surprising move during the latter years of his career (1996-1998), Dieste donated two of his church projects to the archbishopric of Alcala de Henares near Madrid. Thus, it is possible nowadays in Spain to admire some of his building ideas.

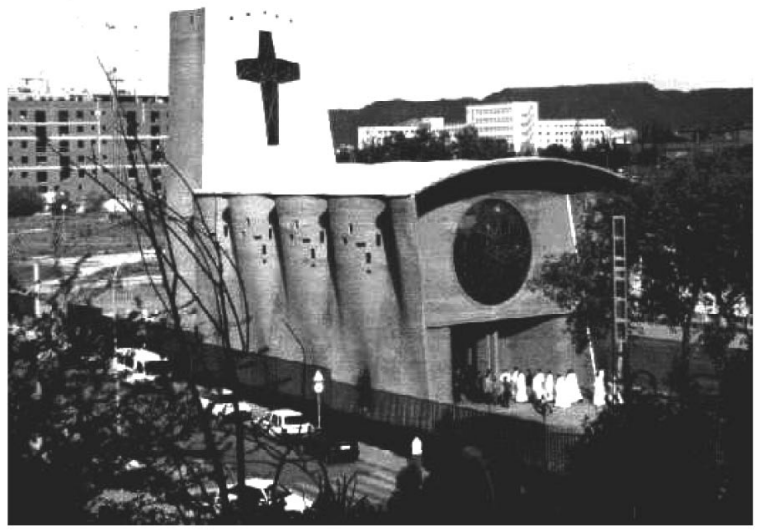

Fig.22 Eladio Dieste. Church of San Juan de Avila. Alcala de Henares (Spain).

The Walls are Modelled after the Atlantida Church

The constructive system employed by Dieste entailed the use of hollow brick blocks ranging in thickness from 15 to 20 centimetres, similar to those laid in hollow core slabs. Thus, the only way to place reinforcements is to insert the bars between the joints of each block, a difficult and time consuming process. Moreover, sliding scaffolding is needed until the 
cement mortar achieves the necessary rigidity and this further complicates construction and increases the required manpower.

By revamping the construction techniques previously described the authors' have implemented a new system that, in parallel with the one used by Torroja, employs both the systems of Catalan vaults and the now available corrugated steel reinforcement. In this situation the reinforcement does not need to be placed between each joint. Instead, it is prefabricated in panels previously calculated by means of the beam theory or by finite element methods as the case may be. This considerably simplifies the process and reduces manpower.

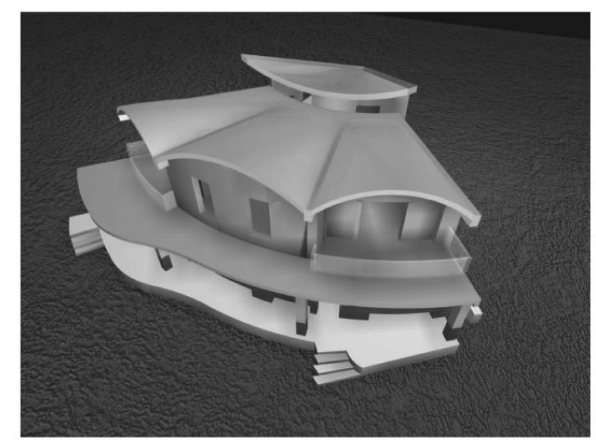

Fig.23. A Computer Model of Calabuig's House entirely Roofed with Ceramic Shells. Jose Maria Cabeza Lainez. Seville (1998)

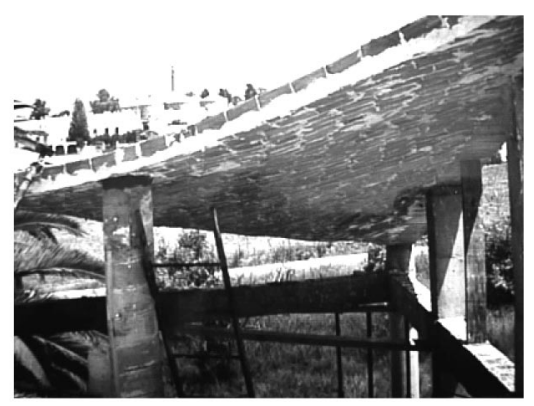

Fig.24. Interior of a Conical Brick Shell at Calabuig's House in Seville (Spain)

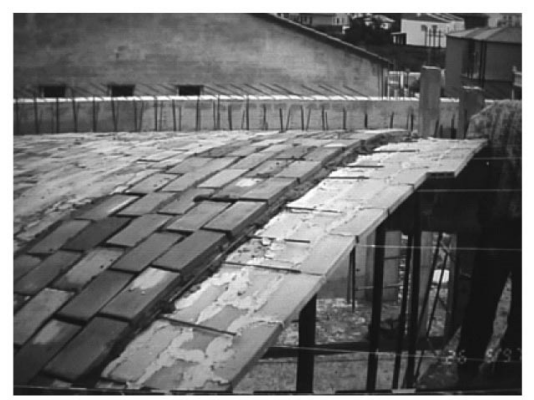

Fig.25. View of the Construction System of the Brick Vaults

Since the first layer is laid with gypsum mortar, permanent forms or scaffolding are not required. The system has been utilized on different buildings

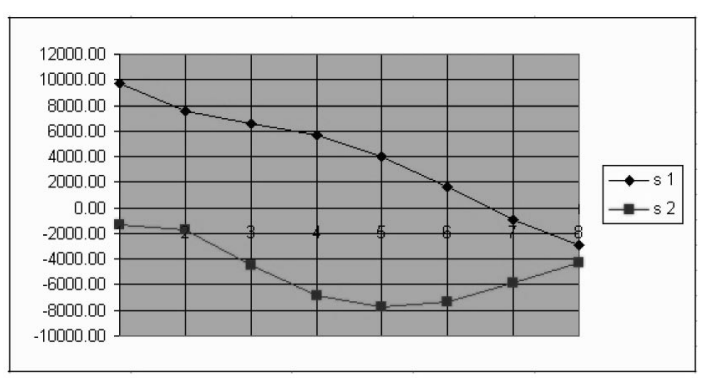

Fig.26. Diagram of the stresses along the principal axes $\sigma_{1}$ and $\sigma_{2}$ in the central vault of the house

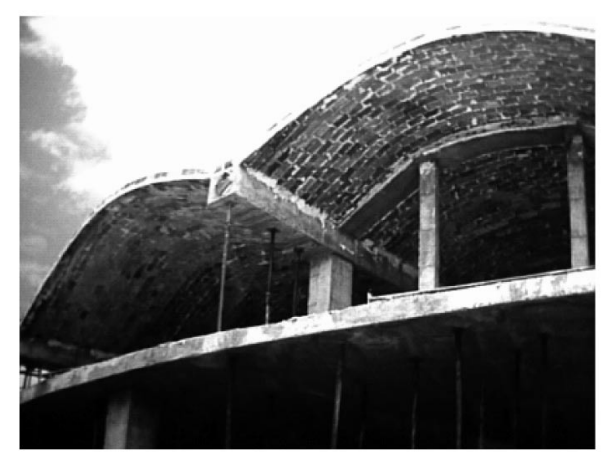

Fig.27. The Central and Side Vaults of Calabuig's House under Construction

in Spain, being efficient, economical and durable. Any inconveniences derived from this new technique appear to be easily resolved or negligible ${ }^{21)}$.

\section{Conclusion}

Apart from the technical aspects, we should not forget the moral dimension enshrined in all Eladio Dieste's oeuvre. It was truly a means to escape from underdevelopment in South America and to give back their lost dignity to the construction workers from the native nations. All the aforementioned led him to create a singular poetics of architecture generated from the essence of matter itself and from the tectonic attributes of the idea. It now seems clear that the challenge addressed to the developed nations by Dieste in his manifesto "Tecnica y Subdesarrollo" (Technique and Underdevelopment) continues to produce new adaptations beyond a given time and place. This, in turn, defies the status quo of contemporary technology and its social and environmental repercussions ${ }^{22}$.

It is expected that such an attitude will encourage the reliance on masonry as a timeless way of building with nature in every region. Consequently, designers, upon using these resources, will become aware of and appreciate their potential. The tableau is thus set for a new American native regionalism to thrive and develop. ${ }^{23)}$

As an epilogue, it might be said that Dieste's oeuvre beautifully embodied that well-known line of Hölderlin: "full of merits but poetically dwells Man on this Earth". ${ }^{24)}$ 


\section{Acknowledgements}

It is the authors' wish to express their deepest gratitude to Professors Cesar Naselli, Noemi Goytia, and Irene Blasco Lucas for their kindness and help in the early research stages of this work in Argentina and Uruguay. Jose Maria Cabeza Lainez is also indebted to the Argentinean Architect Maria Brown Biraben.

The authors' most heartfelt thanks go to the Architect Mariano Arana, a former school companion of Eladio Dieste and now Minister of Housing of Uruguay, who deigned to review part of this text and publicly expressed his enthusiasm about it.

\section{References and Bibliography}

1) S. Anderson, Ed. (2004). Eladio Dieste, Innovation in Structural Art. Princeton Architectural Press. New York.

2) S. Giedion (1971). Architecture and the phenomena of Transition. Harvard University Press.

3) O. F. Bollnow (2000). Mensch und Raum (Man and Space). Kohlhammer. Stuttgart. 2000.

4) R. Guastavino (1893). Essay On The Theory And History Of Cohesive Construction. Ticknor and Company. Boston.

5) J. McAndrew (1965). Open-air Churches of 16th century México. Harvard University Press. Cambridge, p.405.

6) J. M. Cabeza Lainez (2001). The Quest for Daylight. Evolution of domes in South-American baroque. Conference on Passive and Low Energy Architecture (PLEA). Florianopolis (Brazil).

7) T. C. Bannister (1968). The Rousillon Vault. The Apotheosis of a 'Folk' Construction. Journal of the Society of Architectural Historians (JSAH), 27. Number 3, October. Pg. 169, note 83.

8) G. R. Collins. (1968) The Transfer of Thin Masonry Vaulting from Spain to America. Journal of the Society of Architectural Historians (JSAH), 27. Number 3, October.

9) F. Candela (1984). Personal Communication to Jose Maria Cabeza Lainez.

10) Compilation (1975). AC/ G.A.T.E.P.A.C. 1931-1937. Ed. Gustavo Gili. Barcelona.

11) K. Frampton (1995). Studies in Tectonic Culture. The MIT Press. Cambridge, Massachusetts.

12) J. F. Liernur (1997). Tipo, Damero y Tabla Rasa: El Debate Modernista Sobre La Vivienda en Altura en Buenos Aires. Primer Seminario Docomomo Ibérico, Zaragoza.

13) H. Lundgren (1949). Cylindrical Shells. Vol.1 of Cylindrical Roofs. Danish Technical Press. Copenhagen.

14) Wakkanai Minato Kita Bohatei Dome (1985). Hokkaido Kaihatsu Kyoku.

15) G. S. Ramaswamy (1984). Design and Construction of Concrete Shell Roofs. R. E. Krieger. Malabar, Florida.

16) H. Cross (1930). Column Analogy. Engineering Experiment Station Bulletin, $\mathrm{N}^{\mathrm{o}} 215$, Vol. 28, $\mathrm{N}^{\mathrm{o}} 7$. University of Illinois.

17) E. Dieste (1987). La Estructura Cerámica. Ediciones Latinoamericanas. Bogotá.

18) Monograph on the works of Eduardo Torroja (1962). Informes de la Construcción. $N^{\circ}$ 137. Instituto Eduardo Torroja. Madrid.

19) J. A. Loomis (1999). Revolution of Forms. Cuba's Forgotten Art Schools. Princeton University Press. New York.

20) D. Neumann (1999). The Guastavino system in Context: History and Dissemination of a Revolutionary Vaulting Method. APT Bulletin 30, 4.

21) J. M. Cabeza Lainez (2000). Las bovedas de ceramica armada en la obra de Eladio Dieste. III Congreso Nacional de Historia de la Construccion. Instituto Juan de Herrera. Madrid.

22) E. Tedeschi (1969). Teoria e Historia de la Arquitectura. Nueva Visión. Buenos Aires.

23) B. Stagno et al. (2001). Tropical Architecture. Critical Regionalism in the Age of Globalization. John Wiley and sons.

24) Heidegger und Hölderlin/Schriftenreihe (2000). Klostermann. 